UDC 681.5:519.2:622.778

I. K. Mladetsky ${ }^{1}$, Dr. Sc. (Tech.), Prof., orcid.org/0000-0002-6159-6819,

Ya. G. Kuvaiev ${ }^{1}$, Cand. Sc. (Tech.), Assoc. Prof., orcid.org/0000-0003-4981-346X,

N.S. Pryadko ${ }^{2}$, Dr. Sc. (Tech.), Senior Research Fellow, orcid.org/0000-0003-1656-1681
DOI: $10.29202 /$ nvngu/2019-3/17

1 - Dnipro University of Technology, Dnipro, Ukraine, e-mail: kuvaievig@gmail.com

2 - Institute of Technical Mechanics National Academy of Sciences of Ukraine and State Space Agency of Ukraine, Dnipro, Ukraine

\title{
CONTROL REGULARITIES OF THE USEFUL MINERAL EXTRACTION FROM ORE FEED STREAM WITH AUTOGENOUS GRINDING. SPECTRAL ANALYSIS
}

Purpose. Summing up the results of a comprehensive study aimed at substantiating the fundamental decisionmaking base of the control channel of "useful mineral content in ore - useful mineral content in concentrate" in automatic mode for plants, enriching poor iron-containing ores.

Methodology. Comparative analysis of objective indicators of the dispersion spectra, autocorrelation and correlation functions, technological variables, as well as amplitude-frequency characteristics of objects controlling the iron ore dressing processes and general provision synthesis of the mineral processing control system structure.

Findings. Substantiation was initiated regarding the fundamental decision-making base without the participation of the technological process operator based on the relationship between the many states of the control object and the final series of indicative events determined with the combined use of the correlation analysis method of the process variable values and object spectral analysis of iron ore dressing control. The control strategy of these objects, independent of the useful mineral liberation technology, has been determined.

Originality. It was shown for the first time that for all control objects of the poor iron-containing ores dressing, the automatic control system must be built according to the reaction on the deviation of the useful mineral content value at the control object output. For the first time, to substantiate the fundamental decision-making base, the finite series of indicative events was determined with the correlation and spectral analysis method, which are necessary but not sufficient to describe the set of states of the dressing objects of poor iron-containing ores in the control channel of "useful mineral content in ore - useful mineral content in concentrate".

Practical value. The obtained results can be the basis of a promising automatic control system of dressing technology objects for poor iron-containing ores.

Keywords: indicative events, situational control, spectral analysis, frequency analysis, ball grinding, autogenous grinding

Introduction. Regardless of the useful mineral disclose technology at a processing plant, all ore preparation stages are faced with the cyclical change character of the enriched raw material properties. This change character is primarily associated with the beginning and end of such ore production in a quarry, which has various dressing properties that affect the concentrate production. It also has a certain ore supply periodicity to the crushing plant entrance with various transport types. This situation gives rise to the problem of influence of the previous ore preparation stages on the controllability of OCP with autogenous grinding through the "useful mineral content in ore - useful mineral content in concentrate" channel. This should be taken into account for the top level building of the OCP (ore concentration plant) control system, which excludes the operator from the control loop.

It is necessary to note that this work completes a cycle of four articles that with correlation, spectral and frequency analysis offer a problem solution of the subjective current production situation perception by the process operator. The desire to eliminate the "human factor" influence on the technological dressing process is long overdue. The technical base for this solution is

(C) Mladetsky I. K., Kuvaiev Ya. G., Pryadko N. S., 2019 available. The automation level, which is embedded in the already implemented local systems of automatic control and management of individual technological parameters, can be the basis for building a fundamental decision-making base without an operator's participation. The cycle of articles proposes and substantiates the authors' approaches to two problem solution of the top level building: the managing strategy for the poor ironcontaining ore objects and the set of the control object state description with a finite series of indicative events.

Literature review. Foreign and Ukraine mining and processing enterprises have always faced the problems of technological process control, caused by the operator presence in control circuits. At the heart of these problems, there is subjective perception of the current technological situation based on the knowledge and experience of the decision maker (DM). In this regard, a retrospective analysis of the development vectors of automated control systems used in Russian mining and processing plants (MPP) [1] is indicative, which fully corresponds to the situation at Ukrainian mining and processing plants. Attention is drawn to the fact that the same situation also exists in foreign mineral processing industries [2]. Thus, the modern development of theoretical and proven solutions for closed cycle control of autogenous grinding does not depend today on the geo- 
graphical location of the control object and the researcher and engineer teams.

As the practice of autogenous grinding and semiautogenous grinding mill exploitation shows, the main problem is the optimum loading of the mill drum with the grinding material, which allows obtaining the maximum given size class yield. In theoretical conclusions, to determine the loading level of autogenous grinding mills, it is simultaneously proposed to apply indications of "intellectual" pressure sensors in centralized oil lubrication systems of 2 support bearings of the feed and discharge mill pins and the acoustic characteristics of the noise emitted with the grinding material [3]. It is argued that the same goal is achieved with the use of a material stock stabilization circuit in a mill according to the power sensor data consumed by its drive motor and one according to its weight [4]. However, the described methods do not make it possible to exclude the DM from the control circuit of the autogenous grinding mill operating in a closed cycle, since ultimately, for changing the grinding conditions inside the mill drum the DM has to make decisions to adjust the control circuit.

The world leading companies engaged in the development and implementation of integrated solutions for the mining industry, supply modular control systems for grinding and semi-autogenous grinding closed cycles. The functionality of such systems varies widely and depends on customer requirements. They are based on monitoring devices that estimate the values of technological variables (soft sensors). For example, they determine the particle size distribution of the initial mill feed: VisioRock ${ }^{\mathrm{TM}}$, which can be used both in local mode and as a component of a modern control system [5, 6] or a similar solution RockSenceTM [7]. There are control devices that determine the particle size distribution of the ready class (OUTOTEC PSI) [7]. Sensors have been developed based on various indirect methods, evaluating the drum loading with the grinding material: AudioMill $^{\mathrm{TM}}[5,6]$ and MillSence ${ }^{\mathrm{TM}}[7]$.

The SmartMill $^{\mathrm{TM}}$ [2] and BrainWave ${ }^{\mathrm{TM}}$ [8] controllers are the next step in functionality. They are designed to work with individual grinding units and implement the target control function: maximum mill productivity for a given size class. SmartMill ${ }^{\mathrm{TM}}$ realizes predictive control based on a non-linear model. The control algorithms are embedded in the mill drive with varying speed. To bring the system into an optimal state, two control actions are used: the feed of the grinding material and the rotation speed of the mill drum. The BrainWave ${ }^{\mathrm{TM}}$ optimization algorithm is based on the patented model-predictive adaptive control technology, whose essence is not shown. The target control function is similar to SmartMill ${ }^{\mathrm{TM}}$.

Control systems possess the greatest functionality and are described by developers as integrated solutions for the whole processing of mineral raw material. In such systems, multifactor control of the autogenous and semi-autogenous grinding is used due to the complex use of some indirect methods for measuring technological variables. For example, at one of Swedish copper mining factories, $\mathrm{ABB}$ introduced predictive control based on a non-linear facility model, which is configured depending on the objective technical and technological limitations of the control object on which they are implemented [2].

Metso company offers to mining companies distributed control systems for whole process from ore mining to extracting the useful mineral $[5,6]$. A block system diagram and the interaction diagram between its main components are given, the center of which is an expert system with fuzzy logic. According to the diagram in it, the expert system gives the settings to local control systems based on measurements and other received information [6]. The interaction principles and features of the component and local control systems with the expert system are not written. Outotec grinding automation solutions are based on the "Outotec ACT platform" - an advanced control platform that can be connected to any existing enterprise control system [7]. The system is based on linear regression links and an extended Kalman filter and fuzzy logic [9].

Unsolved aspects of the problem. A generalized analysis of materials provided by leading world companies, engaged in the automation of mineral processing technologies, shows the relevance of the problem of eliminating decision makers from control circuits. Today there are no definite statements that the disclosing process and especially mineral raw material dressing, is carried out without the participation of the technological process operator. At best, the problem is solved either for a particular case or for a narrow range of technological variable values, beyond which the DM has to intervene in the control circuit.

For plants with autogenous grinding mills, enriching the poor iron ore, such solutions are completely lacking. Trends in the control system development are aimed at the load increasing on the technological process control at the processing plant, which falls on the DM. This is due to the fact that the control circuits of all typical factory objects, dressing sections, are set on one operator. This situation makes DM do compromise decisions in cases when the process variable values change into more than one dressing section. As a result, the factory begins to work with increased specific energy consumption for the valuable mineral liberation, reducing the productivity on the initial ore.

One of the key points that allow removing DM from the control circuit of the dressing section and the whole factory is determining the moments of strategy change and control tactics on the "useful mineral content in ore - useful mineral content in concentrate" channel. A correlation analysis of the control laws of mineral recovery from ore flows showed that the upper control level of the second ore concentration plant (OCP-2) of the Inhulets Mining and Processing Plant (InMPP) and its separate dressing section on this channel can be based on a number of indicative events [10]. The positive results of using the frequency and spectral analyses for the dressing section with ball grinding and the whole factory for determining indicative events [11] give us reasons for conducting similar studies in the dressing sections with autogenous grinding. 
Results. Above, the reason was described for the cyclical change character of the useful mineral properties at the processing plant inlet with autogenous grinding, which is the control object. Thus, the frequency control object characteristic determines its frequency properties. In our case, for the control channel, "the mineral content in the ore - the mineral content in the concentrate", it should show by how many times the total iron content amplitudes determined by the natural field conditions and its transport features at the processing plant input, are reduced.

The strength and size of the useful mineral impregnation may have their own frequency characteristics, which do not coincide with the frequency characteristics of the mineral content in the ore. Their study is beyond this study scope because these properties of the initial ore affect only the productivity of the concentrating plant and the concentrate yield for a given useful mineral content in the product concentrate.

Previously, in accordance with the technological scheme of connecting OCP-2 devices, we obtained the transfer function of the entire process dressing line (PDL) [10]. We use it to obtain the amplitude-frequency characteristic of the dressing section with autogenous grinding, transforming it into the relation of two polynomials using the software "Mathcad"

$$
W(p)=\frac{a_{0}+a_{1} \cdot p+a_{2} \cdot p^{2}+\cdots+a_{22} \cdot p^{21}}{b_{0}+b_{1} \cdot p+b_{2} \cdot p^{2}+\cdots+b_{23} \cdot p^{22}} .
$$

Further, the polynomial coefficients $a$ and $b$ were found (Table 1)

The polynomial coefficients were used to construct the logarithmic amplitude-frequency characteristic of the dressing section of the OCP-2 InMPP (Fig. 2). To build the characteristics, the software package "Mathlab" was used. Further, only that part of it was considered, on which $\omega_{c f}$ is visible - a cutoff frequency equal to $0.68 \mathrm{rad} /$ hour. The obtained cut-off frequency value corresponds to the fluctuation of total iron content in the initial ore at the dressing section inlet with a period of one and a half hours $\left(T=1 / \omega_{c f}=1.47\right.$ hours $)$.

Thus, the logarithmic amplitude-frequency characteristic of the OCP-2 dressing section of InMPP showed that, according to the control channel, "the useful mineral content in the ore - the useful mineral content in the concentrate", it is necessary to react to the change in the total iron content in the concentrate not earlier than in one and a half hours after fixing this change by means of control. Thus it follows that, theoretically, control strategy for the dressing section with autogenous grinding can be based on a significant deviation of the useful mineral content in the product concentrate.

Let us estimate the filtration properties of the concentration plant with the autogenous grinding of OCP-2 InMPP at the "mineral content in ore - mineral content in concentrate" channel. For this purpose, we determine the amplitude-frequency characteristic, based on the known dispersion spectra ratio of the output signal $-S_{Y}(\omega)$ to the input signal $-S_{X}(\omega)$, which we used for OCP-1 [11]. For our case, $S_{X}(\omega)$ is the dispersion
Table 1

The polynomial transfer function coefficients of dressing section

\begin{tabular}{|c|c|c|}
\hline \multirow{2}{*}{ Index } & \multicolumn{2}{|c|}{ Indication } \\
\hline & $a$ & $b$ \\
\hline 0 & $6.4021 \cdot 10^{-2}$ & $5.5465 \cdot 10^{-1}$ \\
\hline 1 & $1.7756 \cdot 10^{-1}$ & 2.7509 \\
\hline 2 & $1.7979 \cdot 10^{-1}$ & 5.7203 \\
\hline 3 & $8.7236 \cdot 10^{-2}$ & 6.5554 \\
\hline 4 & $2.1559 \cdot 10^{-2}$ & 4.5854 \\
\hline 5 & $2.617 \cdot 10^{-3}$ & 2.048 \\
\hline 6 & $1.359 \cdot 10^{-4}$ & $5.9388 \cdot 10^{-1}$ \\
\hline 7 & $1.8981 \cdot 10^{-6}$ & $1.1174 \cdot 10^{-1}$ \\
\hline 8 & $1.1433 \cdot 10^{-8}$ & $1.3448 \cdot 10^{-2}$ \\
\hline 9 & $3.3684 \cdot 10^{-11}$ & $1.0037 \cdot 10^{-3}$ \\
\hline 10 & $4.9446 \cdot 10^{-14}$ & $4.4147 \cdot 10^{-5}$ \\
\hline 11 & $3.4879 \cdot 10^{-17}$ & $1.0902 \cdot 10^{-6}$ \\
\hline 12 & $9.4489 \cdot 10^{-21}$ & $1.6462 \cdot 10^{-8}$ \\
\hline 13 & $3.5214 \cdot 10^{-29}$ & $1.6314 \cdot 10^{-10}$ \\
\hline 14 & $1.8075 \cdot 10^{-31}$ & $1.1085 \cdot 10^{-12}$ \\
\hline 15 & $6.3142 \cdot 10^{-34}$ & $5.287 \cdot 10^{-15}$ \\
\hline 16 & $1.5118 \cdot 10^{-36}$ & $1.7846 \cdot 10^{-17}$ \\
\hline 17 & $2.463 \cdot 10^{-39}$ & $4.2449 \cdot 10^{-20}$ \\
\hline 18 & $2.6668 \cdot 10^{-42}$ & $6.9964 \cdot 10^{-23}$ \\
\hline 19 & $1.8275 \cdot 10^{-45}$ & $7.7433 \cdot 10^{-26}$ \\
\hline 20 & $7.1486 \cdot 10^{-49}$ & $5.4479 \cdot 10^{-29}$ \\
\hline 21 & $1.2135 \cdot 10^{-52}$ & $2.1897 \cdot 10^{-32}$ \\
\hline 22 & 0 & $3.8147 \cdot 10^{-36}$ \\
\hline
\end{tabular}

spectrum of total iron in the initial ore (Fig. 2), and $S_{Y}(\omega)$ is the dispersion spectrum of total iron in the concentrate (Fig. 3).

For each series of observations, the average value of the total iron content in the concentrate and its disper-

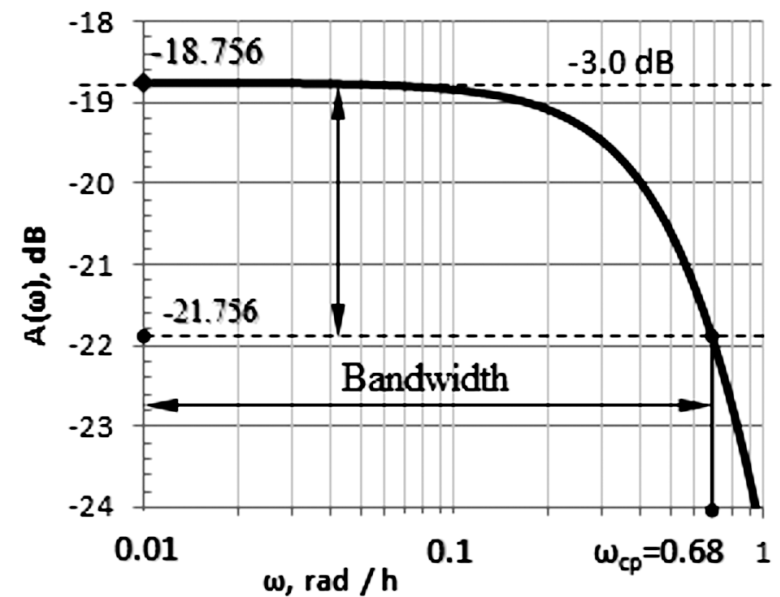

Fig. 1. Logarithmic amplitude-frequency characteristic of the OCP-2 dressing section of InMPP 

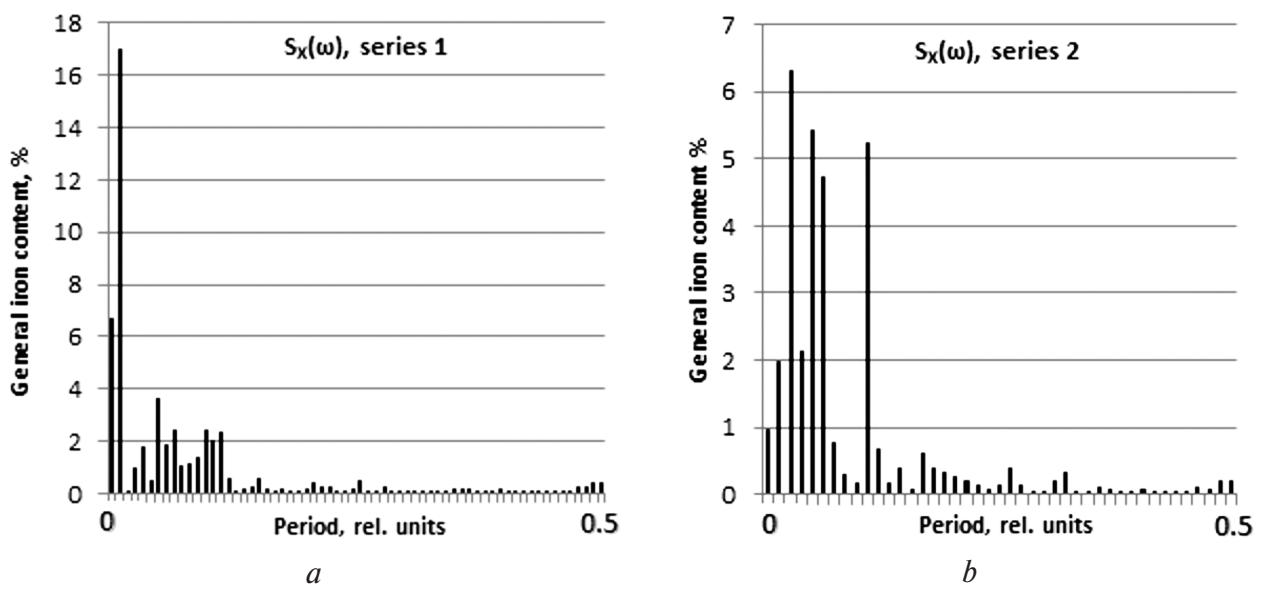

Fig. 2. The dispersion spectrum of the total iron content in the initial ore for OCP-2: $a-S_{X}(\omega)$, series $1 ; b-S_{X}(\omega)$, series 2


Fig. 3. The dispersion spectrum of total iron in concentrate for $O C P-2$ :

$a-S_{Y}(\omega)$, series $1 ; b-S_{Y}(\omega)$, series 2

sion are constant. This made it possible to carry out spectral analysis using autocorrelation functions. It is known that the autocorrelation function is even. Therefore, before the spectral analysis, it was supplemented with the corresponding values, which are located to the left of the ordinate axis. Taking into account these values, the implementation length for the first series of observations was 128 hours, and for the second -86 . The sampling frequency for the observation series is the same and is one hour ${ }^{-1}$.

The form of the dispersion spectra (Figs. 2, 3) shows that the low frequencies have the greatest amplitude for all series of observations. Moreover, the amplitude of the iron content in the initial ore at low frequencies has significant fluctuations: from 16 to $2 \%$. However, the main part of the spectrum has amplitude in the range of $2 \%$. The amplitude of the low frequency spectrum of iron content in the concentrate is not more than $4 \%$. It ranges from $2.5 \%$ for the first observation series and $3 \%$ for the second observation series. For both observation series of the dispersions spectra of the total iron content in the concentrate, there is a tendency for the amplitudes to fall from low to medium frequencies at an exponential law. In all dispersion spectra the amplitude of the high-frequency component is present; however, it is closed to zero.
According to the dispersion spectrum form of the total iron content in the initial ore, it is possible to hypothesize that it displays the ore preparation operation frequencies that precede the OCP-2 storage bin feeding with the initial ore, from which the ore enters the dressing sections. The lowest frequencies most likely correspond to the raw material formation processes in the quarry. The right side of the low-frequency spectrum for the first observation series corresponds to the natural averaging of the raw material properties in the OCP-2 storage bin. It occurs because of the ore mixing due to the transverse shift of its layers relative to the longitudinal bunker axis. The shift of the ore layers is a consequence of its uneven production at the dressing sections.

Pairwise comparison of the dispersion spectra of total iron content in the initial source ore and concentrate for both observation series suggests that low frequencies corresponding to the ore preparation processes at the recovery stage and ore transportation to the crushing unit inputs pass to the OCP-2 output. However, the amplitude values are significantly smoothed and, as noted above, they descend to higher frequencies (the right side of the low-frequency spectrum) according to an exponential law. Consequently, the amplitudes of the frequencies, which, according to our hypothesis, corre- 
spond to the processes occurring in the OCP-2 bunker, are substantially smoothed, having five times smaller amplitude than at the factory input.

The total spectrum of the output signal OCP-2 was obtained for each observation series according to the following algorithm. For each individual frequency, the average spectra amplitude values of the input signals for all sections were calculated. Further, for each observation series the amplitude-frequency characteristic of OCP-1 was obtained using the control channel of "mineral content in ore - mineral content in concentrate" based on the characteristics of the initial data (Figs. 4, $a, b$ ). The features of the source data and the expression used to obtain the amplitude-frequency characteristic were described earlier [11].

The type of amplitude-frequency characteristics obtained for the first observation series shows that the constant component of valuable mineral content in the initial product has the most significant effect on the quality indicators of the concentrate. The right part of the middle spectrum part shows the effect on the dressing indicators of the initial ore flow formation, primarily due to the unevenness of the initial ore indicators, coming from the OCP-2 storage bin to the dressing sections with autogenous. In our case, we define the maximum spectrum amplitude at the boundary of its low and mid-frequency part as the interference, the nature of which we could not establish.

The amplitude-frequency characteristic of the second observation series has a number of significant differences from the first observation series:

- the maximum amplitudes of the first observation series, which we did not identify as interference, are 1.5 times smaller than the maximum amplitudes of the second observation series;

- the amplitude of the constant component tends to zero, which means that the useful mineral content in the raw material does not affect the concentrate quality;

- the maximum amplitudes are absent in the lowfrequency part of the spectrum.

Such features of the amplitude-frequency characteristics allow saying that the spectrum formation of the second observation series is not influenced considerably by the useful mineral content in the raw materials. The spectrum is formed by the processes of OCP-2 incorporation into the operation, which entail changes in the dressing process parameters initiated by the staff in order to bring the dressing process to regular operating modes.

Summing up the research. This publication is the last in four article cycle devoted to the control laws of the useful mineral recovery from ore flows, which take place in the processing dressing lines of poor iron-containing ores of the Inhulets MPP [10-12]. The cycle begins with an article devoted to the study with the correlation analysis method of the results of the iron ore dressing process line, in which ball grinding is used for useful mineral liberation [12]. Further, for the same line, the results of iron ore concentration with the spectral analysis method [11] were investigated. In the third [10] and the present article, similar studies were carried out for dressing units in which autogenous grinding mills are used for useful mineral liberation.

In the course of these studies, the work of 10 sections of OCP-1 (ball grinding) and 13 sections of OCP-2 (autogenous grinding) of the Inhulets mining complex was analyzed. For each section, two observation series were analyzed. The first and second observation series were carried out in one period of time for all sections of the iron ore dressing. All sections operated in the normal mode of production exploitation in the stationary season (summer) conditions. The observation duration is five days, the discreteness is one hour.

Correlation (Table 2) and spectral (Table 3) analysis of the OCP-1 and OCP-2 dressing sections operation showed that the control object behavior on the "the useful mineral content in ore - the useful mineral content in concentrate" channel weakly depends on the structure of the technological iron ore dressing lines and a method for useful mineral liberation.

This permits us to speak about the unified flowchart of the dressing control object not only of poor iron ores, but also of any other mineral, where this process begins with the mineral liberation, continues with the libera-
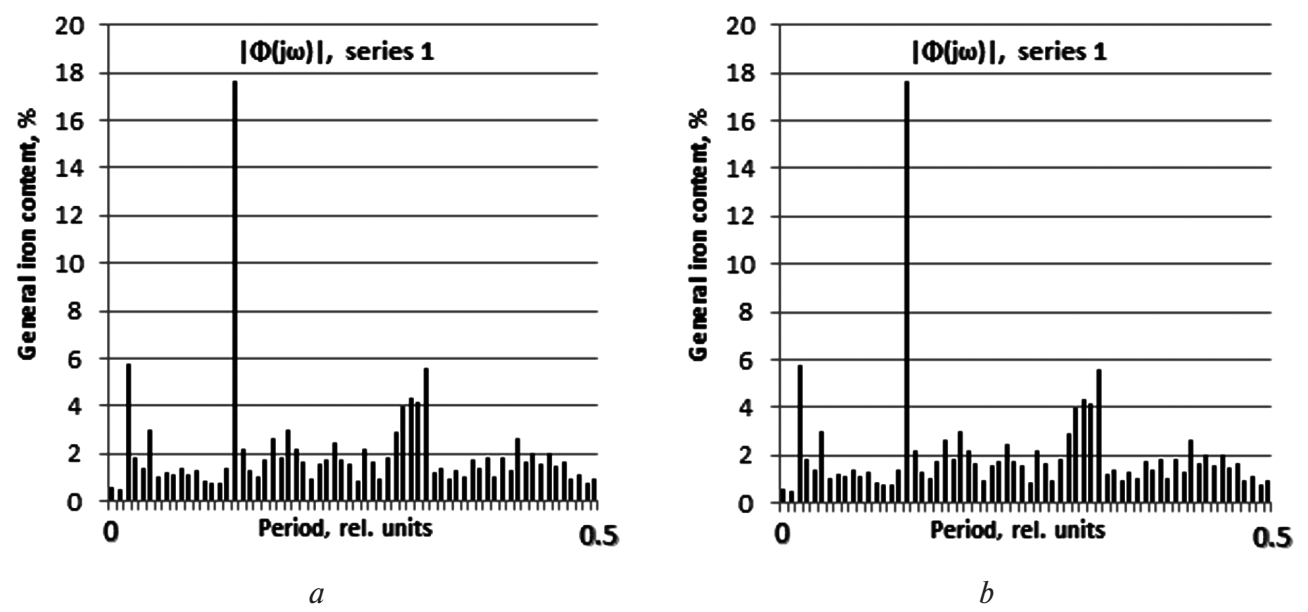

Fig. 4. Amplitude-frequency characteristics of OCP-2:

$a$ - the first observation series; $b$ - the second observation series 
Table 2

The correlation analysis results of total iron content in the initial ore, concentrate and tailings for OCP-1 and OCP-2 of Inhulets MPP

\begin{tabular}{|c|c|c|c|c|c|}
\hline № & Object of study & \multicolumn{2}{|c|}{ OCP-1 } & \multicolumn{2}{|c|}{ OCP-2 } \\
\hline 1. & $\begin{array}{l}\text { Transition time in the processing } \\
\text { line, hours }\end{array}$ & \multicolumn{2}{|c|}{16} & \multicolumn{2}{|c|}{20} \\
\hline 2. & The observation series & 1 & 2 & 1 & 2 \\
\hline \multirow[t]{3}{*}{3.} & \multicolumn{5}{|c|}{$\begin{array}{l}\text { The decay time of the autocorrelation function of } \\
\text { total iron, hour: }\end{array}$} \\
\hline & feedstock (ore) & 5 & 13 & 22 & 5 \\
\hline & depleted product (tails) & 20 & 13 & - & - \\
\hline \multirow[t]{3}{*}{4.} & \multicolumn{5}{|c|}{$\begin{array}{l}\text { The decay time of the autocorrelation function of total } \\
\text { iron content in an enriched product (concentrate), } \\
\text { hours: }\end{array}$} \\
\hline & minimum & 3 & 3 & 4 & 2 \\
\hline & maximum & 15 & 8 & 17 & 15 \\
\hline \multirow[t]{3}{*}{5.} & \multicolumn{5}{|c|}{$\begin{array}{l}\text { The equivalent delay time of the correlation function } \\
\text { of the total iron content in the enriched product from } \\
\text { its content in the initial raw material, h: }\end{array}$} \\
\hline & minimum & 17 & 20 & 54 & 30 \\
\hline & maximum & 34 & 38 & 59 & 37 \\
\hline 6. & $\begin{array}{l}\text { The correlation function sign of } \\
\text { the total iron content in the } \\
\text { enriched product from its content } \\
\text { in the initial raw materials }\end{array}$ & + & - & + & - \\
\hline
\end{tabular}

tion result classification and ends with the useful mineral recovery (Fig. 5).

Thus, we can draw a flowchart of a concentrating plant consisting of unified control units of iron ore dressing (Fig. 6).

In the present study, the control laws of a useful mineral recovery from ore flows were established for the control channel of "the useful mineral content in the ore - the useful mineral content in the concentrate". According to the unified flowchart of the control object
Table 3

Parameters of logarithmic frequency characteristics of dressing sections of OCP- 1 and OCP- 2 of the Inhulets MPP

\begin{tabular}{|c|l|c|c|}
\hline \multirow{2}{*}{ № } & \multicolumn{1}{|c|}{ Parameters } & \multicolumn{2}{c|}{ Object name } \\
\cline { 3 - 4 } & & OCP-1 & OCP-2 \\
\hline 1 & Polynomial numerator degree & 22 & 23 \\
\hline 2 & Polynomial denominator degree & 21 & 22 \\
\hline 3 & Cutoff frequency LAFH, dB & 0.22 & 0.68 \\
\hline 4 & $\begin{array}{l}\text { Oscillation period of the raw } \\
\text { material properties, } h\end{array}$ & 4.54 & 1.47 \\
\hline
\end{tabular}

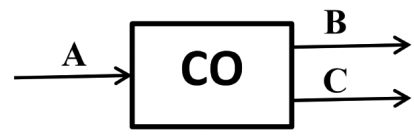

Fig. 5. Unified flowchart of the control unit of the poor iron-containing ore dressing:

$A$ - initial ore; $B$-enriched product; $C$-depleted product

of the poor iron-containing ore dressing (Fig. 5) and the generalized flowchart of the concentration plant (Fig. 6) we take the following name for the control channel, corresponding to the flowchart: "the useful mineral content in the raw materials - the useful mineral content in the enriched product".

All of the following generalizations are valid for all control objects, which can be represented by the flowcharts shown above (Figs. 5, 6), if the type of autocorrelation functions of the useful mineral content in the raw materials and enriched product makes it possible to conclude that all processes in the considered technology are stationary and ergodic for any observation series.

1. The weak correlation between the useful mineral content in the enriched product and in the initial raw material or its absence suggests that the control object is operating in the steady mode.

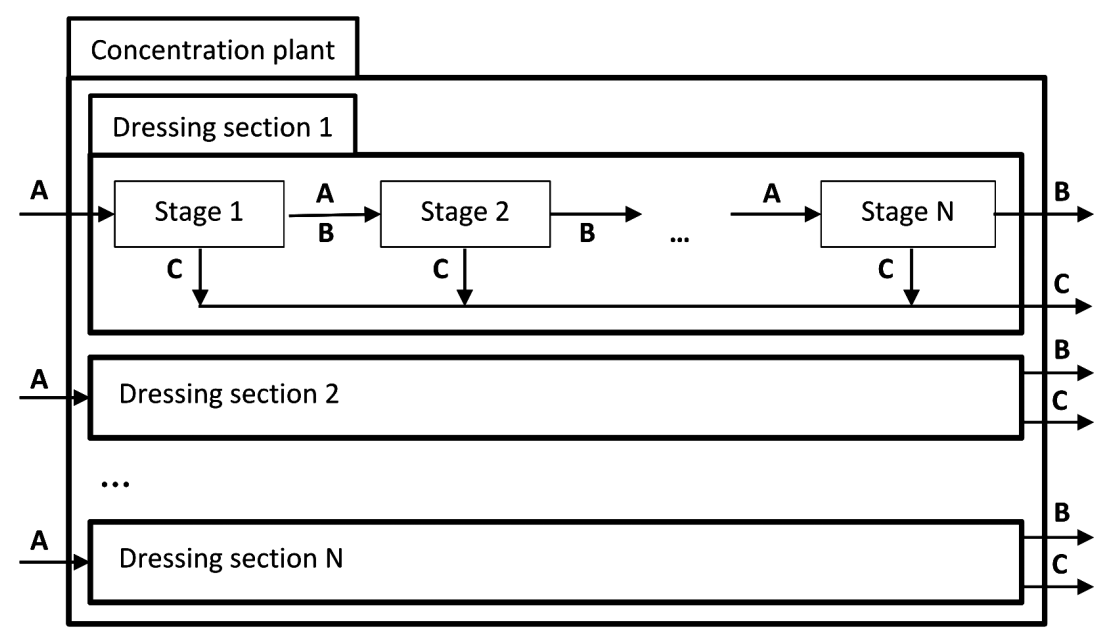

Fig. 6. A generalized flowchart of the concentrating plant as a control object:

$A$ - initial ore; $B$ - enriched product; $C$ - depleted product 
2. The positive correlation between the valuable mineral content in the initial minerals and the enriched product suggests that the dressing operates in a steady mode according to the dressing index of initial minerals.

3. The negative correlation between the valuable mineral content in the initial minerals and the enriched product corresponds to the transitional mode of the production line due to the staff actions to give the desired direction to the process.

4. If the decay time of the autocorrelation function of the useful mineral content in an enriched product is less than the time of the transition process, then by the time of its termination the initial information is hopelessly outdated, therefore, the deviation control becomes impossible.

5. If the time of the equivalent delay of the correlation function of the a useful mineral content in an enriched product from its initial raw material content is longer than the transient process time, then the disturbing effect due to a change in the dressing raw material characteristics does not affect the useful mineral content in the enriched product, although the technological process continues to work out the static relationship between the useful mineral content in the initial minerals and in the enriched product.

6. If the correlation function type of the useful mineral content in an enriched product from its content in the initial minerals does not correspond to the classical ideas about it, then it can be claimed that the control object is operating in a transitional mode.

7. The cutoff frequency values and the oscillation period of the useful mineral in the initial raw material (Table 3 ) confirm the theoretical possibility of the control system design for the control objects (Figs. 5, 6) according deviation on "the useful mineral content in the initial raw material - the useful mineral content in the enriched product" channel.

8. Hypothesis. The left part of the low frequency dispersion spectrum of the useful mineral content in the initial minerals describes the formation processes of its concentration characteristics directly in the quarry.

9. Hypothesis. The right-hand part of the low frequencies of the dispersion spectrum of the useful mineral content in the raw materials describes the formation processes of its dressing characteristics due to accumulation and segregation in the bunker, which feeds the control object input.

10. Comparison of the dispersion spectra of the useful mineral content in the raw materials and enriched product allowed asserting that only low frequencies are transmitted to the control object output, corresponding to the formation of the dressing characteristics of the raw materials directly in the deposit. The formation of dressing characteristics caused by the accumulation and segregation of the raw material in the bunker feeding the control object, are not observed at its output in the enriched product stream.

11. If the constant component of the valuable mineral content and the unevenness of its indicators, determined by the amplitudes of the middle part of the spectrum of the amplitude-frequency characteristic, in the initial product have corresponding effects on the useful mineral content in the enriched product, then the control object operates in a steady state.

12. If the amplitude of the constant component is almost zero and the amplitude maximum values belong to high frequencies of the amplitude-frequency characteristic, then the control object operates in a transient mode, which is caused by changes in the parameters of the dressing process initiated by the staff.

\section{Conclusions.}

1. Analysis of the logarithmic amplitude-frequency characteristic of the dressing section of the OCP-2 InMPP leads to the conclusion that theoretically the control strategy of the dressing section at the "mineral content in ore - mineral content in concentrate" channel coincides with the section control strategy OCP-1 [11]. It does not depend on the dressing scheme and the useful mineral liberation method and should be based on fixing a significant deviation from the specified properties of the market concentrate.

2. If we take into account the fact that OCP-2 with autogenous grinding, as well as OCP-1 with ball grinding [11], are parallel working same-type sections (in our case there are 13 ones for OCP-2 and 10 for OCP-1), the control strategy for a separate section extends to the factory as a whole, regardless of the method of the useful mineral liberation.

3. Analysis of the dispersion spectra of total iron content in the initial ore and concentrate and the amplitude-frequency characteristics of the OCP-2 showed that the control capabilities of the "the useful mineral content in the ore - the useful mineral content in the concentrate" channel to ensure the specified mineral content in the concentrate is determined by the mineral content in the initial ore, formed in the deposit. They are weakly dependent on the processes of ore preparation, which precede the ore feeding from the factory storage bunker to the dressing sections inputs.

4. The amplitude-frequency characteristic type of OCP-2 is an indicator of the operating mode of the processing plant on the control channel of "the useful mineral content in the ore - the useful mineral content in the concentrate" regardless of the liberation method and the dressing circuit (see the corresponding conclusion [11]).

5. The steady-state signs of OCP-2 operation mode with autogenous grinding and signs of its operation in a transient mode completely coincide with those that were previously defined for OCP-1 with ball grinding [11] according to the type of its amplitude-frequency characteristic. They can be used in the automatic control system of the processing plants as indicative events that determine their operation modes without the participation of staff.

6. For any control object of mineral processing, which corresponds to a unified and generalized flowchart (Figs. 5, 6), the following signs can be listed, corresponding to its operating in the steady mode on the control channel of "the useful mineral content in the raw materials - the useful mineral content in the enriched product": 
- weak or positive correlation between the content of valuable mineral in the initial ore and the enriched product;

- the constant component of the valuable mineral content and the non-uniformity of its indicators, determined by the amplitudes of the middle spectrum part of the amplitude-frequency characteristic, have corresponding effects in the initial product on the useful mineral content in the enriched product.

7. For any object control of mineral processing, which corresponds to a unified and generalized flowchart (Figs. 5, 6), you can list the following signs corresponding to the transition process on the control channel of "the useful mineral content in the raw material the useful mineral content in the enriched product":

- negative correlation between the valuable mineral content in the initial ore and the enriched product;

- the type of the correlation function of the mineral content in the enriched product from its content in the initial ore does not correspond to the classical ideas about it;

- the constant component amplitude is almost zero and the maximum amplitudes belong to the high frequencies of the amplitude-frequency characteristic.

8 . The control system of any mineral processing facility that corresponds to a unified and generalized flowchart (Figs. 5, 6) can theoretically be and should be based on a significant deviation of the mineral content in the enriched product.

\section{References.}

1. Enderev, V.A. (2012). The state and prospects of development of the management system of mining and processing industry in ferrous metallurgy. Modern research and innovation, 8. Retrieved from http://web. snauka.ru/issues/2012/08/16352.

2. Perrucci, M., Martin, M., \& Ferreau, J. (2015). SmartMill_TM: Exceed your performance limits. Take full control of your grinding mills to increase productivity. ABB Ltd, Zurich, Switzerland. Retrieved from https://library.e.abb.com/public/1f0ebafac7e1475db76 62c43c106dc03/WhitePaper_Smart\%20Mill_LowRes. pdf.

3. Sibirtseva, N. B., Potapenko, A. N., \& Semiletov, N. A. (2010). Methods of measuring the level of loading mills, based on the physical processes of modern centralized lubrication systems. News of the Samara Scientific Center of the Russian Academy of Sciences, 4(3), 694-697.

4. Andreev, E. E., Nikolaev, N. V., \& Lviv, V. V. (2011). The method of automatic control of the operation of the mill autogenous. Notes of the Mining Institute, 192, 6164.

5. Metso Group (2012). Optimizing the process with Metso CISA. Helsinki, Finland. Retrieved from http://www. madencilik-turkiye.com/dosyalar/metso/sunum7-julie_legay-prosesi_tamamlayici_uygulamalar.pdf. 6. Metso Group (2013). Minerals Processing Solutions. Automation. Helsinki, Finland. Retrieved from http:// www.metso.com/miningandconstruction/mm_proj. nsf/WebWID/WTB-131030-2256F-1C5EA/\$File/ Metso\%20Automation\%202013.pdf.
7. OUTOTEC (2017). OUTOTEC automation solutions for grinding optimization. Espoo, Finland. - Retrieved from https://www.outotec.com/globalassets/products/ analyzers-and-automation/ote_act_grinding_optimization_eng.pdf.

8. ANDRITZ (2015). Control systems for partial selfgrinding mills. Graz, Austria. Retrieved from https:// www.andritz.com/resource/blob/14846/87c53c36290c d5c943e75b006ba2f877/aa-brainwave-sagmill-ru-data. pdf.

9. OUTOTEC (2014). OUTOTEC Act Platform (2014). Espoo, Finland. Retrieved from https://www.outotec. com/globalassets/products/analyzers-and-automation/ ote_act_platform_eng.pdf .

10. Mladetsky, I. K., Kuvaiev, I.G., \& Priadko, N.S. (2018). The control regularity detection of the useful mineral extraction from the ore feed stream with autogenous grinding. Part 1. Correlation analysis. Naukovyi Visnyk Natsionalnoho Hirnychoho Universytetu, 4(166), 59-65. DOI: 10.29202/nvngu/2018-4/6.

11. Mladetsky, I. K., Kuvaiev, I.G., \& Priadko, N.S. (2017). Control regularities of the useful mineral extraction from ore feed stream with ball grinding. Spectral analysis. Naukovyi Visnyk Natsionalnoho Hirnychoho Universytetu , 6(162), 132-138.

12. Mladetsky, I. K., Kuvaiev, I.G., \& Priadko, N.S. (2017). Naukovyi Visnyk Natsionalnoho Hirnychoho Universytetu , 4(160), 91-98.

\section{Закономірності керування вилученням корисного мінералу з рудопотоків із самоподрібненням. Спектральний аналіз}

\section{I. К. Младецький', Я. Г. Куваєв ${ }^{1}$, Н. С. Прядко ${ }^{2}$}

1 - Національний технічний університет „Дніпровська політехніка“, м. Дніпро, Україна, e-mail: kuvaievig@gmail. com

2 - Інститут технічної механіки НАН України, Державна Космічна Агенція України, м. Дніпро, Україна

Мета. Підведення підсумків комплексного дослідження, що спрямоване на обгрунтування фундаментальної бази прийняття рішень по каналу керування „вміст корисного мінералу в руді - вміст корисного мінералу в концентраті““ в автоматичному режимі для фабрик, що збагачують бідні залізовмісні руди.

Методика. Порівняльний аналіз об’єктивних показників спектрів дисперсій, автокореляційних і кореляційних функцій, технологічних змінних, а також амплітудно-частотних характеристик об'єктів управління процесами збагачення залізної руди й синтез загальних положень структури систем управління збагаченням корисних копалин.

Результати. Покладено початок обгрунтуванню фундаментальної бази прийняття рішень без участі оператора технологічного процесу на основі зв'язку між безліччю станів об'єкта керування й кінцевим рядом індикативних подій, що визначаються спільним використанням методу кореляційного аналізу значень технологічних змінних і спектрального 
аналізу об'єктів керування збагаченням залізної руди. Визначена стратегія керування такими об'єктами, що не залежить від технології розкриття корисного мінералу.

Наукова новизна. Уперше показано, що для всіх об'єктів керування збагаченням бідних залізовмісних руд систему автоматичного керування необхідно будувати по реакції на відхилення значення вмісту корисного мінералу на виході об’єкта керування. Уперше для обгрунтування фундаментальної бази прийняття рішень методом кореляційного та спектрального аналізу був визначений кінцевий ряд індикативних подій, необхідних, але не достатніх, для опису безлічі станів об'єктів керування збагаченням бідних залізовмісних руд по каналу керування „вміст корисного мінералу в руді - вміст корисного мінералу в концентраті“.

Практична значимість. Отримані результати можуть стати основою перспективної системи автоматичного керування об'єктами технологій збагачення бідних залізовмісних руд.

Ключові слова: індикативні подї, ситуаційне управління, спектральний аналіз, частотний аналіз, кульове подрібнення, самоподрібнення

\section{Закономерности управления извлечением полезного минерала из рудопотоков с самоизмельчением. Спектральный анализ}

\section{И. К. Младецкий ${ }^{1}$, Я. Г. Куваев ${ }^{1}$, Н. С. Прядко ${ }^{2}$}

1 - Национальный технический университет „Днепровская политехника“", г. Днепр, Украина, e-mail: kuvaievig@ gmail.com

2 - Институт технической механики НАН Украины, Государственное Космическое Агентство Украины, г. Днепр, Украина

Цель. Подведение итогов комплексного исследования, направленного на обоснование фундаментальной базы принятия решений по каналу управления „содержание полезного минерала в руде - содержание полезного минерала в концентрате“" в автоматическом режиме для фабрик, обогащающих бедные железосодержащие руды.
Методика. Сравнительный анализ объективных показателей спектров дисперсий, автокорреляционных и корреляционных функций, технологических переменных, а также амплитудно-частотных характеристик объектов управления процессами обогащения железной руды и синтез общих положений структуры систем управления обогащением полезных ископаемых.

Результаты. Положено начало обоснованию фундаментальной базы принятия решений без участия оператора технологического процесса на основе связи между множеством состояний объекта управления и конечным рядом индикативных событий, определяемых совместным использованием метода корреляционного анализа значений технологических переменных и спектрального анализа объектов управления обогащением железной руды. Определена стратегия управления этими объектами, не зависящая от технологии раскрытия полезного минерала.

Научная новизна. Впервые показано, что для всех объектов управления обогащением бедных железосодержащих руд систему автоматического управления необходимо строить по реакции на отклонение значения содержания полезного минерала на выходе объекта управления. Впервые для обоснования фундаментальной базы принятия решений методом корреляционного и спектрального анализа был определён конечный ряд индикативных событий, необходимых, но не достаточных, для описания множества состояний объектов управления обогащением бедных железосодержащих руд по каналу управления „содержание полезного минерала в руде - содержание полезного минерала в концентрате“.

Практическая значимость. Полученные результаты могут стать основой перспективной системы автоматического управления объектами технологий обогащения бедных железосодержащих руд.

Ключевые слова: индикативные события, ситуационное управление, спектральный анализ, частотный анализ, шаровое измельчение, самоизмельчение

Рекомендовано до публікації докт. техн. наук В. В. Ткачовим. Дата надходження рукопису 04.04.18. 